\title{
Geleneksel Olarak Üretilen Bitlis Tulum Peyniri ve Bazı Kimyasal Kalite Özellikleri
}

\author{
Hakan SANCAK ${ }^{1}$, Özgür İşLEYICİ ${ }^{2 *}$, Rabia Mehtap TUNCAY², Yakup Can SANCAK ${ }^{2}$ \\ ${ }^{1}$ Bitlis Eren Üniversitesi, Tatvan Meslek Yüksekokulu, Gıda İşleme Bölümü, Tatvan, Bitlis \\ ${ }^{2}$ Van Yüzüncü Yıl Üniversitesi, Veteriner Fakültesi, Besin Hijyeni ve Teknolojisi Bölümü, Van
}

\begin{abstract}
Öz
$\mathrm{Bu}$ araştırma, Bitlis yöresinde geleneksel olarak üretilen tulum peynirinin tanıtılması ve bazı kimyasal kalite özelliklerinin belirlenmesi amacıyla yapılmıştır. Bu amaçla; Bitlis ilinde satışa sunulan 36 adet peynir örneği materyal olarak kullanılmıștır. Örneklerin kimyasal analizleri sonucunda ortalama kuru madde miktarı $\% 59.349 \pm 2.657$, yağ miktarı $\% 31.231 \pm 3.783$, kuru maddede yağ miktarı $\% 52.530 \pm 5.192$, protein miktarı $\% 22.641 \pm 1.243$, tuz miktarı $\% 3.351 \pm 0.809$, kuru maddede tuz miktarı $\% 5.660 \pm 1.393$, kül miktarı $\% 3.771 \pm 0.529$ ve titrasyon asitliği değeri de $1.112 \pm 0.122 \%$ Laktik asit olarak tespit edilmiştir. Türk Gıda Kodeksi Peynir Tebliği'ne göre; incelenen örneklerin \%91.67'sinin tam yağlı ve \%8.33'ünün ise yağlı tulum peyniri sinıfina girdiği, \%97.22'sinin kuru madde ve \%38.89'unun da tuz miktarı yönünden uygun olduğu belirlenmiştir. Bitlis tulum peyniri örnekleri arasında kimyasal özellikler yönünden farklılıklar olduğu ve belli bir kalite standardının bulunmadığı görülmüsşür. Diğer yandan peynir örneklerinin içerdikleri yağ ve protein miktarları açısından; besleyici değeri yüksek bir süt ürünü oldukları söylenebilir. Araştırma sonucunda; Bitlis tulum peynirinin incelenen kimyasal kalite özellikleri yönünden standart bir üretiminin olmadığı ortaya konulmuş, bu peynirin modern şartlarda standardize bir şekilde üretilmesi durumunda öncelikle iç pazar payının artabileceği ve buna bağlı olarak da bölgenin ekonomik kalkınmasına önemli katkılar sağlayabileceği sonucuna varılmıştır.
\end{abstract}

Anahtar kelimeler: Bitlis tulum peyniri, kimyasal kalite, geleneksel üretim.

\section{Traditionally Produced Bitlis Tulum Cheese in Turkey and Its Some Chemical Quality Properties}

\begin{abstract}
This study was in order to introduce of the tulum cheese traditionally produced in Bitlis region and to determine some of its chemical quality properties. For this purpose, 36 cheese samples put up for sale in Bitlis province were used as material. As a result of the chemical analyses of the samples was determined the average dry matter content as $59.349 \pm 2.657 \%$, fat content as $31.231 \pm 3.783 \%$, fat content in the dry matter as $52.530 \pm 5.192 \%$, protein content as $22.641 \pm 1.243 \%$, salt content as $3.351 \pm 0.809 \%$, salt content in the dry matter as $5.660 \pm 1.393 \%$, ash content as $3.771 \pm 0.529 \%$, and titratable acidity value as $1.112 \pm 0.122 \%$ Lactic acid. It was determined that $91.67 \%$ of the samples examined were in the category of full fat and $8.33 \%$ were in the category of fat tulum cheese; $97.22 \%$ and $38.89 \%$ were suitable in accordance with the Turkish Food Codex Cheese Communiqué in terms of dry matter content and salt content, respectively. It was observed that there were differences between the Bitlis tulum cheese samples in terms of chemical properties and there was not a certain quality standard. On the other hand, in terms of the amount of fat and protein content of cheese samples; it can be said that they are a dairy product with high nutritive value. As a result of the study, it was revealed that there was not a standardized production of the examined Bitlis tulum cheese in terms of chemical quality properties and it was concluded that its domestic market share may increase in case that standardized production of this cheese is realized in modern conditions and accordingly it may significantly contribute to the economic development of the region.
\end{abstract}

Keywords: Bitlis tulum cheese, chemical quality, traditional production.

*Sorumlu yazar: oisleyici@yyu.edu.tr

Geliş Tarihi: 04.06.2018, Kabul Tarihi: 25.10.2018 


\section{Giriş}

Peynir, üretildiği hammaddeye ve üretim şeklindeki farkl1lıklara bağlı olarak tüm dünyada çok eski zamanlardan beri çeşitli lezzet ve formlarda üretilen en önemli süt ürünlerindendir. Eski zamanlarda çabuk bozulan sütün değerlendirilmesi amacıyla yapılan peynir, günümüzde daha çok lezzeti ve besleyici özelliklerinden dolayı sevilerek tüketildiği için üretilmektedir.

Dünyadaki peynir çeşitliliği insanların tercihleri ve yöre kültürlerine göre devamlı artmış ve tüm dünyada üretilen peynir çeşidinin yaklaşık 1000 civarında olduğu bildirilmiştir [1]. Bulunduğu coğrafya, sahip olduğu zengin tarihsel ve kültürel mirastan köken alan mutfağı ile Türkiye, 130 civarında peynir çeşidinin üretildiği önemli bir ülkedir. Başta beyaz peynir ve kaşar peyniri gibi yaygın ve bol miktarda üretilen peynirler olmak üzere tulum peyniri, otlu peynir, lor peyniri, çömlek peyniri ve küp peyniri gibi çok farklı geleneksel peynirleri ile zengin bir çeşitliliğe sahiptir [2].

Türkiye'nin sevilerek tüketilen geleneksel peynirlerinden olan tulum peynirleri; ülkenin birçok yerinde, özellikle de sütün modern işletmelerde değerlendirilemediği köy ve kasabalardaki küçük aile işletmelerinde üretilmektedir. Ancak son yıllarda tüketicilerin beğenisi ve taleplerindeki artı̧̧a bağlı olarak modern işletmelerde de önemli miktarlarda üretim yapılmaya başlanmıştır.

Tulum peyniri; koyun, keçi, inek, manda sütü veya bunların karışımından üretilen, ufalanabilen yapıda ve yarı sert bir peynir çeşididir. Genel olarak kuru tulum peyniri yapılırken süt yaklaşık $30^{\circ} \mathrm{C}$ ' de mayalanır, 60-90 dakikada pıhtılaşır ve oluşan pıhtı 2-3 $\mathrm{cm}^{3}$ büyüklügünde parçalanır. Bazen peyniraltı suyu ayrılmadan önce teleme yaklaşık $45{ }^{\circ} \mathrm{C}$ civarında 15-20 dakika 1sıtılır. Parçalanan teleme bez torbalara alınır ve peyniraltı suyunun ayrılması için yaklaşık 30 dakika asılı bırakılır. Daha sonra bez torba üzerine ağırlık konularak yaklaşık $30-40 \mathrm{~g} / \mathrm{cm}^{2}$ lik basınç altında 2-3 saat baskıya alınır. Serumu ayrılan teleme değişik araçlarla veya sadece elle 3-5 $\mathrm{mm}^{3}$ 'lük küçük parçalar haline getirilir, \%2-5 oranında tuzlanarak tüylü kısmı dış tarafta olacak şekilde özel hazırlanan tulumlara doldurulur ve hiç boşluk bırakılmadan sıkıca basılır. Dolumdan sonra üst kısma biraz tuz serpilerek tulum dikilir ve $\% 85$ nispi rutubete sahip 4-6 ${ }^{\circ} \mathrm{C}^{\prime}$ lik serin bir yerde (soğuk oda, ev bodrumu, mağara) yaklaşık 90-120 gün süreyle olgunlaşmaya bırakılır $[3,4,5,6]$.

Bu yapım şeklinden farklı olarak daha çok Ege bölgesinde üretimi yapılan salamura tulum peynirleri de telemenin kalıp şeklinde kesilmesi ve genellikle içi laklı tenekelerde tuzlu salamura ile olgunlaştırılması gibi farklı üretim teknikleri ile karakterize önemli bir tulum peyniri çeşidi olarak dikkati çekmektedir. Üretimde önce süt 30 dakika $60-65^{\circ} \mathrm{C}$ 'de 1 sıtılldıktan sonra yaklaşı $1 \mathrm{k} 35^{\circ} \mathrm{C}$ 'ye kadar soğutulur ve mayalanır. Mayalamadan sonra 45-50 dakikada pıhtılaşma oluşur, süzme bezine alınan teleme asılarak veya üzerine ağırlık konularak baskılanır ve peyniraltı suyu 3-5 saatte uzaklaştırılır. Teleme bloklar halinde kesilerek kuru tuzlama yapılır ve oksidasyon için 24 saat bekletilir. Daha sonra kalıplar laklı teneke ambalajlara bırakılıp tuzlanmış peynirin suyunu salarak salamura oluşması beklenir. Salamura suyu eksik ise \%12-16'lık salamura suyu eklenerek tamamlanır ve peynirler 1 hafta boyunca $14-15{ }^{\circ} \mathrm{C}^{\prime}$ de ön olgunlaştırma işleminden sonra $4-6{ }^{\circ} \mathrm{C}^{\prime}$ de depolanır $[5,7,8,9,10]$. Türkiye'de tulum peynirlerinin yoğun olarak üretildiği bölgeler Şekil 1'de gösterilmiştir.

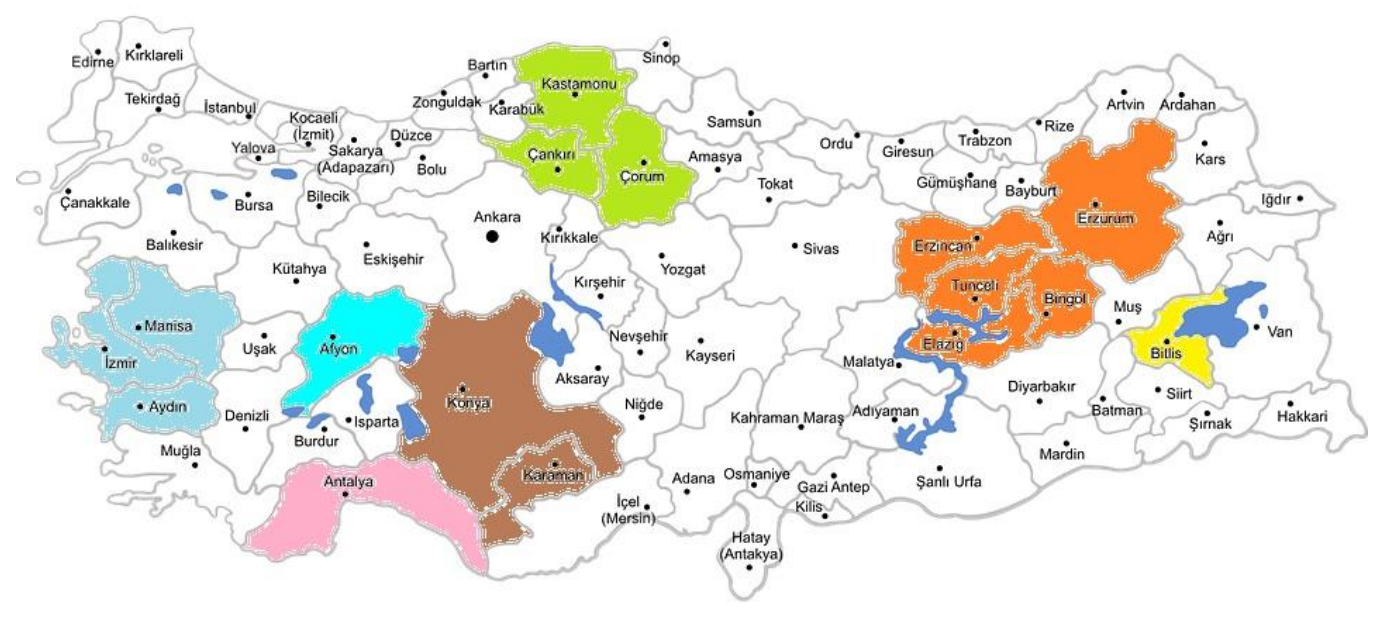

Şekil 1. Türkiye'de tulum peynirlerinin yoğun olarak üretildiği bölgeler 
Üretimde uygulanan teknikler ve üretildiği bölgelere göre farklılıklar gösteren tulum peyniri, genellikle Erzincan, Erzurum, Elazı̆g, Tunceli ve Bingöl'de Şavak tulum peyniri, Çorum, Kastamonu ve Çankırı'da Kargı tulum peyniri, Karaman ve Konya'da Divle tulum peyniri, Antalya ve çevresinde Çimi tulum peyniri ve Ege Bölgesi'nde de İzmir tulumu olarak adlandırılmaktadır. Bitlis tulum peyniri de geleneksel tulum peyniri çeşitlerinden olup, ülke genelinde çok fazla tanınmasa da bölgede üretimi yaygın bir şekilde yapılan ve sevilerek tüketilen bir peynir çeşididir.

\subsection{Geleneksel Bitlis Tulum Peyniri Üretimi}

Bitlis ve çevresinde daha çok küçük aile işletmeleri ve mandıralarda genellikle Nisan-Haziran ayları ile Temmuz-Ağustos ayları arasında olmak üzere iki dönemde üretilmektedir. İlk dönemde üretilen peynirlerde kullanılan sütün kuru madde miktarı düşük olduğundan tüketiciler bu dönemde üretilen peynirlerden ziyade ikinci dönem üretilen peynirleri tercih etmektedirler.

Bitlis tulum peynirinin üretiminde daha çok koyun ve keçi sütü kullanılmakta, tüketici tercihlerine göre inek sütünden de yararlanılmaktadır. Bazen bu üç çeşit sütün karıştırılmasıyla elde edilen sütlerle de üretim yapılabilmektedir. Sadece koyun sütü kullanılarak yapılan peynirler çok yağlı ve belirgin bir kokuya sahip oldukları için tüketimde fazla tercih edilmemekte ve bundan dolayı koyun sütü ile inek sütünün birebir oranında karıştırılmasıyla da peynir üretilmektedir.

Üretimi çok yaygın olmamakla birlikte bölgede otlu tulum peyniri de yapılmaktadır. Bu türlü üretimde Hizan ve Mutki ilçeleri başta olmak üzere yüksek rakımlı yaylalar ile Bitlis, Tatvan ve Reşadiye çevresinden bahar aylarında toplanan ve Van Otlu peyniri üretiminde de kullanılan sirmo (Allium sp.), heliz (Prangos sp., Ferula sp.) ve mendi (Anthriscus nemorosa) ile birlikte, Bitlis ve çevresinde so (sof-soğ-soh-sov; Heracleum sp.) ve ağarçe (ağırçe; Allium sp.) isimleriyle bilinen otlar kullanılmaktadır. Bölgede yetişen bu otlar (Şekil 2,3) kokusu daha az hissedildiği ve hafif bir lezzete sahip olduklarından dolayı bazı tüketiciler açısından tercih sebebi olmaktadır.

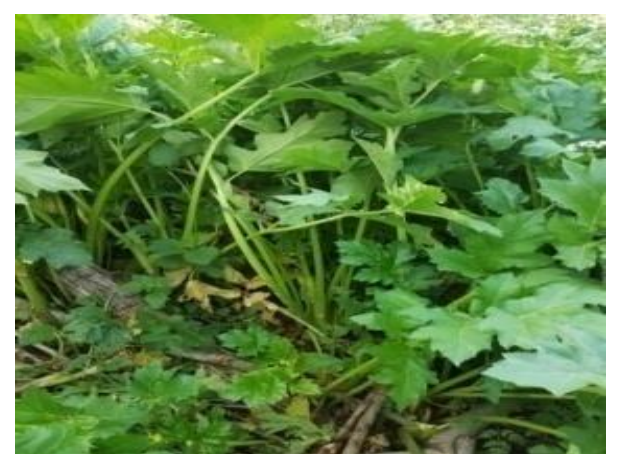

Şekil 2. So (Heracleum sp.)

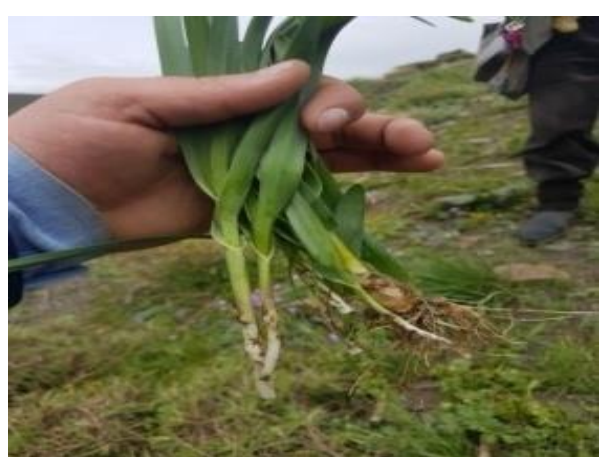

Şekil 3. Ağarçe (Allium sp.)

Bitlis tulum peyniri üretiminde; sağım sonrası süzülen süt, genellikle pastörize edilmeden sağım sıcaklığında veya yaklaşık $30-40{ }^{\circ} \mathrm{C}$ civarına kadar ısıtıldıktan sonra ticari maya kullanılarak mayalanır. Mayalamadan 2-3 saat sonra oluşan pihtı parçalanarak serin bir yerde ilk önce süzme bezinde yaklaşık bir gün ve daha sonra da altı delinmiş şeffaf poşetlerde yaklaşı 3-4 gün suyunun tamamen uzaklaştırılması amaciyla bekletilir. Bu süre sonunda elle veya tahta sopalarla ufalanan peynir \%3-4 civarında kaya tuzu ile karıştırılır ve bez çuvallara basılarak ağız kısımları sıkıca bağlanır. Çuvallar üst üste gelecek şekilde istiflenir ve gün aşırı aktarılıp en üst kısma ağırlık konularak ilk dönem sütlerinden yapılanlar 8-10 gün, ikinci dönem sütlerinden yapılanlar ise 5-6 gün süreyle bekletilir. Bu peynir üretiminde kullanılan ufalama makinesinde (Şekil 4) yaklaşık nohut tanesi büyüklügünde parçalanan teleme, şimşir ağacından yapılmış nem tutmayan tokmaklar veya çelik çubuklarla genellikle $1 \mathrm{~kg}$ 'lık, 2 kg'lık, 5 kg'llk ve 10 kg'lık plastik bidonlara hava boşluğu kalmayacak şekilde sıkıca basılır. 


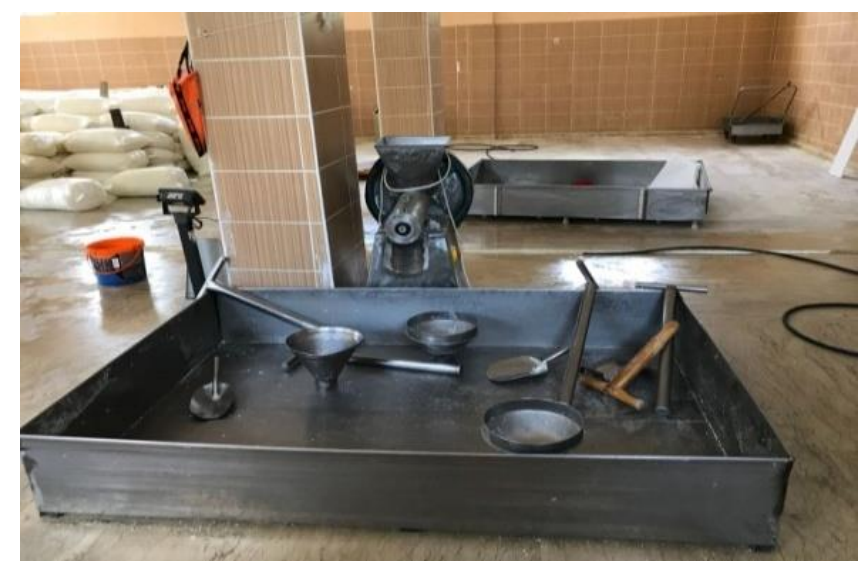

Şekil 4. Peynir ufalama makinesi

En üst kısma geniş çaplı yapraklar, poşet veya bez parçası bırakılarak bidonların ağzı plastik kapakları ile hava almayacak şekilde kapatılır ve iple sıkıca bağlanır. Üretilen peynirlerin geleneksel olarak olgunlaştırılması; peynir basılan kapların ters çevrilip toprağa gömülmesi, toprak üstünde pomza taşı ve ince kum ile etrafı çevrilerek serin bir ortamda bekletilmesi veya direkt olarak soğuk hava depolarında tutulması olmak üzere üç farklı şekilde yapılmaktadır. Bitlis tulum peyniri bölgede 20-30 günlük olgunlaşma süresinden sonra bile tüketilmekte, tam olgunlaştırma için ise 90-150 günlük bir bekletme süresi uygulanmaktadır (Şekil 5 ve Şekil 6).

Diğer tulum peynirlerinden farklı olarak Bitlis tulum peyniri bölgede bulunan pomza ocaklarında da olgunlaştırılabilmektedir.

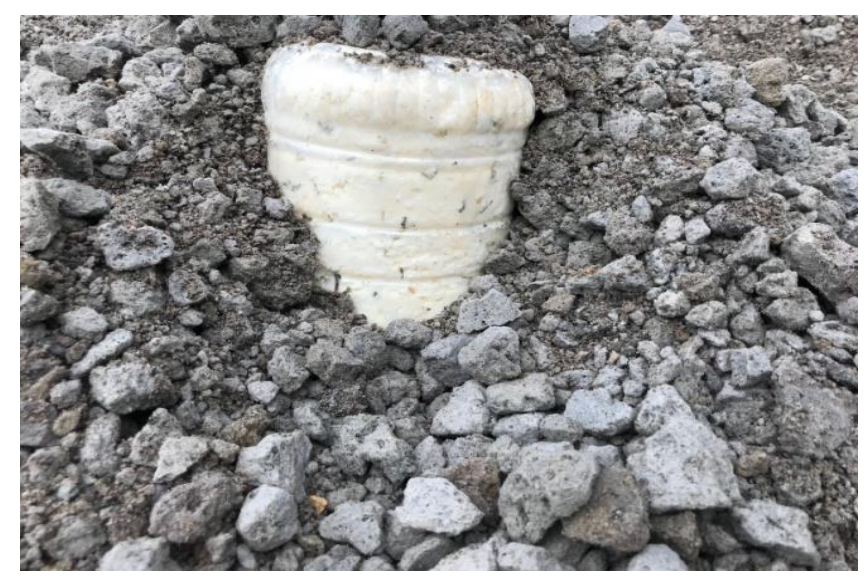

Şekil 5. Pomza ocaklarında olgunlaştırılan Bitlis tulum peyniri

Peynirin, toprak üstünde olgunlaştırılmasında kullanılan pomza taşı; gözenekli bir yapıya sahip, gözenekleri birbirinden camsı bir tabaka ile ayrılan ve çevrelediği ortamın ısısını koruma özelliği ile bilinen doğal yalıtım malzemesi niteliğinde bir madendir [11].

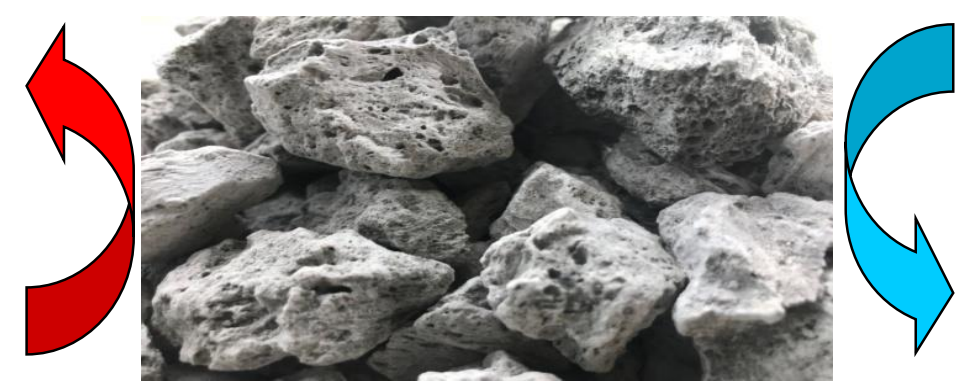

Şekil 6. Pomza taşı 
Bitlis ve çevresindeki pomza ocaklarında, genellikle çalışanlar tarafindan muhafaza edilen ve Kasım-Aralık aylarına doğru çıkarılarak tüketilen Bitlis tulum peyniri, tam olgunlaştığı ve daha lezzetli olduğu için tercih edilebilmektedir.

Bitlis tulum peynirlerinin pomza ocaklarında, Divle tulum peynirlerinin de obruklarda bekletilmesi peynirlerin serin bir ortamda bekletilerek olgunlaştırılması açısından benzerlik göstermektedir.

Eskiden küplere (Şekil 7) basılarak üretilen Bitlis tulum peyniri, günümüzde kullanım kolaylığı ve ekonomik olmasından dolayı daha çok plastik bidonlarda (Şekil 8) üretilmektedir.

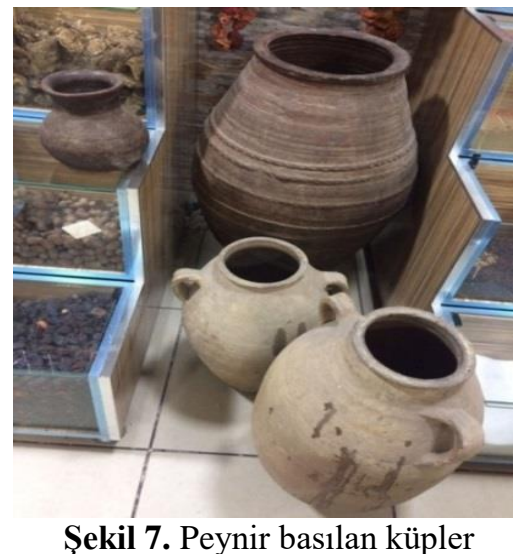

Üretimde hammadde olarak genellikle çiğ süt kullanıldığından, doğal mikrofloraya bağlı olarak farklı lezzet ve aromaya sahip olan Bitlis tulum peynirleri elde edilmekte, üretim daha çok küçük aile işletmelerinde ve farklı yöntemlerle yapıldığından dolayı da her zaman standart kalite özelliklerine sahip ürünler üretilememektedir.

$\mathrm{Bu}$ araştırmada Bitlis tulum peynirinin geleneksel üretim şekli ortaya konularak, bazı kimyasal kalite özelliklerinin belirlenmesi ve bu niteliklerin yasal kriterlere uygunluğunun tespit edilmesi amaçlanmıştır.

\section{Materyal ve Metot}

\subsection{Materyal}

Analizlerde Bitlis ilindeki market, şarküteri ve kahvaltı salonlarından toplanan 36 adet Bitlis tulum peyniri örneği materyal olarak kullanılmıştır. Peynir örnekleri aseptik şartlarda cam kavanozlara yaklaşık 200 g civarında alınmış ve soğuk zincirde laboratuvara getirilerek en kısa sürede analizleri yapılmıştır.

\subsection{Metot}

\subsubsection{Kimyasal analizler}

Peynir örneklerindeki kuru madde miktarı (KM) gravimetrik yöntemle, yağ miktarı Gerber metoduyla, protein miktarı Kjeldahl metoduyla, tuz miktarı Mohr metoduyla, kül miktarı kül fırınında yakma yöntemiyle ve asitlik değeri de titrasyon metodu ile \%Laktik asit (\%LA) olarak tespit edilmiştir. Kuru maddede yağ (KMY) ve kuru maddede tuz (KMT) miktarları ise hesaplama yöntemiyle belirlenmiştir [12].

\subsection{2. İstatistiksel analizler}

İncelenen örneklerden elde edilen KM (\%), yă (\%), KMY (\%), protein (\%), tuz (\%), KMT (\%), kül (\%) ve asitlik (\%L.A.) bulguları arasındaki ilişki korelasyon analizi ile SPSS 23.0 paket programı kullanılarak belirlenmiştir. Önemlilik derecesi $p<0.05$ ve $p<0.01$ olarak alınmıştır [13]. 


\section{Bulgular ve Tartışma}

Analize alınan Bitlis tulum peyniri örneklerinde tespit edilen kimyasal analiz bulguları Tablo 1'de verilmiştir.

Tablo 1. Bitlis tulum peyniri örneklerinde belirlenen kimyasal analiz bulguları

\begin{tabular}{|c|c|c|c|c|c|c|c|c|}
\hline $\begin{array}{c}\text { Örnek } \\
\text { No }\end{array}$ & $\begin{array}{l}\text { KM } \\
(\%)\end{array}$ & $\begin{array}{l}\text { Yă } \\
(\%)\end{array}$ & $\begin{array}{c}\text { KMY } \\
(\%) \\
\end{array}$ & $\begin{array}{c}\text { Protein } \\
(\%)\end{array}$ & $\begin{array}{l}\text { Tuz } \\
(\%)\end{array}$ & $\begin{array}{c}\text { KMT } \\
(\%)\end{array}$ & $\begin{array}{l}\text { Kül } \\
(\%)\end{array}$ & $\begin{array}{l}\text { Asitlik } \\
\text { (\% LA) }\end{array}$ \\
\hline 1. & 60.070 & 34.000 & 56.601 & 20.919 & 6.318 & 10.518 & 3.430 & 0.957 \\
\hline 2. & 56.690 & 32.000 & 56.447 & 24.477 & 4.797 & 8.462 & 4.779 & 0.891 \\
\hline 3. & 60.510 & 32.000 & 52.884 & 22.352 & 4.680 & 7.734 & 5.607 & 0.825 \\
\hline 4. & 60.430 & 33.000 & 54.609 & 23.526 & 2.691 & 4.453 & 3.292 & 0.858 \\
\hline 5. & 61.360 & 38.000 & 61.930 & 23.319 & 2.808 & 4.576 & 3.897 & 1.040 \\
\hline 6. & 60.240 & 35.000 & 58.101 & 22.087 & 2.574 & 4.273 & 2.812 & 1.200 \\
\hline 7. & 61.270 & 35.000 & 57.124 & 23.032 & 2.691 & 4.392 & 3.565 & 1.056 \\
\hline 8. & 57.470 & 31.000 & 53.941 & 21.414 & 2.574 & 4.479 & 4.270 & 1.188 \\
\hline 9. & 62.160 & 31.000 & 49.871 & 22.831 & 2.691 & 4.329 & 3.982 & 1.200 \\
\hline 10. & 61.390 & 34.000 & 55.384 & 23.277 & 3.393 & 5.527 & 3.786 & 1.056 \\
\hline 11. & 58.090 & 30.000 & 51.644 & 21.482 & 3.276 & 5.640 & 4.177 & 1.155 \\
\hline 12. & 58.980 & 32.000 & 54.256 & 21.847 & 3.276 & 5.554 & 3.585 & 1.155 \\
\hline 13. & 58.070 & 32.000 & 55.106 & 22.786 & 2.691 & 4.634 & 3.506 & 0.990 \\
\hline 14. & 59.190 & 34.000 & 57.442 & 22.891 & 2.574 & 4.349 & 3.291 & 1.122 \\
\hline 15. & 59.460 & 33.000 & 55.499 & 21.829 & 3.276 & 5.510 & 3.853 & 1.023 \\
\hline 16. & 59.380 & 34.000 & 57.258 & 22.924 & 3.510 & 5.911 & 4.300 & 1.188 \\
\hline 17. & 62.790 & 33.000 & 52.556 & 22.153 & 2.808 & 4.472 & 3.156 & 1.023 \\
\hline 18. & 59.720 & 32.300 & 54.086 & 22.714 & 2.808 & 4.702 & 4.309 & 1.188 \\
\hline 19. & 59.680 & 32.000 & 53.619 & 22.509 & 3.042 & 5.097 & 3.099 & 1.023 \\
\hline 20. & 59.220 & 32.000 & 54.036 & 24.341 & 4.212 & 7.112 & 4.148 & 1.188 \\
\hline 21. & 68.460 & 37.000 & 54.046 & 25.458 & 3.042 & 4.443 & 3.979 & 1.254 \\
\hline 22. & 61.210 & 34.000 & 55.546 & 22.007 & 3.510 & 5.734 & 3.529 & 1.056 \\
\hline 23. & 57.960 & 31.000 & 53.485 & 23.484 & 3.744 & 6.460 & 3.654 & 1.188 \\
\hline 24. & 60.460 & 32.000 & 52.928 & 24.418 & 4.914 & 8.128 & 3.723 & 0.990 \\
\hline 25. & 58.550 & 30.000 & 51.238 & 23.207 & 2.925 & 4.996 & 3.294 & 1.056 \\
\hline 26. & 58.090 & 22.000 & 37.872 & 23.425 & 3.393 & 5.841 & 3.841 & 1.221 \\
\hline 27. & 57.600 & 27.000 & 46.875 & 25.856 & 3.276 & 5.687 & 3.611 & 1.089 \\
\hline 28. & 60.290 & 30.000 & 49.759 & 20.851 & 3.744 & 6.210 & 4.053 & 1.188 \\
\hline 29. & 57.900 & 21.000 & 36.269 & 22.397 & 3.510 & 6.062 & 3.409 & 1.254 \\
\hline 30. & 58.440 & 31.000 & 53.046 & 20.183 & 3.276 & 5.606 & 2.898 & 1.023 \\
\hline 31. & 52.420 & 25.000 & 47.692 & 21.616 & 2.808 & 5.357 & 4.078 & 1.353 \\
\hline 32. & 59.340 & 30.000 & 50.556 & 20.925 & 2.574 & 4.338 & 3.533 & 1.122 \\
\hline 33. & 52.470 & 22.000 & 41.929 & 22.365 & 3.510 & 6.690 & 3.572 & 1.254 \\
\hline 34. & 60.240 & 32.000 & 53.121 & 22.406 & 3.042 & 5.050 & 4.066 & 1.287 \\
\hline 35. & 57.800 & 31.000 & 53.633 & 21.857 & 3.978 & 6.882 & 3.612 & 1.188 \\
\hline 36. & 59.170 & 30.000 & 50.701 & 21.903 & 2.691 & 4.548 & 4.071 & 1.155 \\
\hline Minimum & 52.420 & 21.000 & 36.269 & 20.183 & 2.574 & 4.273 & 2.812 & 0.825 \\
\hline Maksimum & 68.460 & 38.000 & 61.930 & 25.856 & 6.318 & 10.518 & 5.607 & 1.353 \\
\hline Ortalama & 59.349 & 31.231 & 52.530 & 22.641 & 3.351 & 5.660 & 3.771 & 1.112 \\
\hline S. Sapma & 2.657 & 3.783 & 5.192 & 1.243 & 0.809 & 1.393 & 0.529 & 0.122 \\
\hline
\end{tabular}

$\mathrm{Bu}$ araştırmada Bitlis ve çevresinde geleneksel yöntemlerle üretilerek market, şarküteri ve kahvaltı salonlarında tüketime sunulan Bitlis tulum peynirinin bazı kimyasal özellikleri incelenmiştir. Yapılan literatür taramasına göre bu çalışma Bitlis tulum peynirinin bazı kimyasal özelliklerinin tespit edildiği ilk çalışma niteliği taşımaktadır. Bu peynir çeşidinden elde edilen bulguların Türkiye'de üretilen diğer tulum peyniri ve benzer peynir çeşitlerinden elde edilen kimyasal analiz bulguları ile karşılaştırılması Tablo 2'de görülmektedir.

Bitlis tulum peynirlerinde $\% 59.349 \pm 2.657$ olarak belirlenen ortalama kuru madde miktarı genel olarak benzer peynirlerde yapılan araştırmalarda elde edilen sonuçlardan yüksek bulunurken, Karg1 tulum peynirinde [19] tespit edilen değerden düşük bulunmuştur (Tablo 2). Bu durum büyük ölçüde 
tulum peynirlerinin üretiminde kullanılan hammaddenin bileşimi, üretim teknikleri ve olgunlaştırma şartlarının farklı olmasından kaynaklanmaktadır. İncelenen örneklerin sadece 1 tanesinin (\%2.78) Türk Gıda Kodeksi Peynir Tebliği'nde [22] belirtilen en çok \%45 rutubet oranına uygun olmadığ belirlenmiştir. İlgili mevzuatta kuru maddede yağ oran $1 \% 45$ 'ten az olan tulum peynirlerine nem oran için \% 5 eklenmesi istendiğinden, 33 No'lu örnek de standartlara uygun olarak değerlendirilmiştir (Tablo 1). Örneklerde belirlenen kuru madde miktarı ile kül miktarı arasında negatif yönlü istatistiksel bir ilişki $(p<0.05)$ tespit edilmiştir. Bu durumun peynir örneklerinin genellikle yüksek miktarlarda yağ içermesi ve bu yüksek yăg miktarının kuru madde miktarını arttırmasına karşılık kül miktarını tam tersi yönde etkilemesiyle ilişkili olduğu düşünülmektedir.

Tablo 2. Türkiye'de tulum peynirleri ve benzer peynirlerde belirlenen kimyasal analiz bulguları

\begin{tabular}{|c|c|c|c|c|c|c|c|c|c|c|}
\hline Peynir çeşidi & $\mathbf{N}$ & $\% \mathrm{KM}$ & \% Yă̆ & $\% \mathrm{KMY}$ & $\%$ Protein & $\% \mathrm{Tuz}$ & $\% \mathrm{KMT}$ & $\%$ Kül & Asitlik & Kaynak \\
\hline Divle tulum peyniri & 28 & 57.14 & 25.15 & 45.02 & 25.98 & 3.36 & 5.89 & 5.059 & $76.70 \mathrm{SH}$ & Gönç [4] \\
\hline Erzincan tulum Peyniri & 20 & 59.47 & 30.89 & - & 22.91 & - & - & 4.86 & - & Demirci [14] \\
\hline Şavak tulum peyniri & 26 & 53.21 & 28.20 & 52.77 & 18.51 & 3.44 & 6.56 & 4.73 & $1.834 \% \mathrm{LA}$ & Kurt ve ark. [15] \\
\hline Erzincan tulum peyniri & 17 & 53.69 & 27.76 & - & 16.91 & 3.44 & - & 5.22 & $1.608 \% \mathrm{LA}$ & Diğrak ve ark. [16] \\
\hline Divle tulum peyniri & 20 & 57.01 & 21.30 & - & - & 3.006 & - & 3.784 & $0.497 \% \mathrm{LA}$ & Keleş ve Atasever [17] \\
\hline Sivas küp peyniri & 25 & 49.52 & 9.44 & 18.61 & 24.78 & 4.53 & - & 13.28 & $0.87 \% \mathrm{LA}$ & Pekel ve Korukoğlu [18] \\
\hline Karg1 tulum peyniri & 6 & 65.34 & 20.53 & 31.37 & 21.37 & 3.69 & - & - & $0.62 \% \mathrm{LA}$ & Dinkçi ve ark. [19] \\
\hline Divle tulum peyniri & 50 & 56.27 & 23.46 & 41.50 & 25.90 & 3.99 & 7.17 & 4.96 & $1.074 \% \mathrm{LA}$ & Morul ve İşleyici [20] \\
\hline Afyon tulum peyniri & 25 & 53.69 & 25.68 & - & 22.48 & 4,02 & - & 4.62 & $0.51 \% \mathrm{LA}$ & Kara ve Akkaya [21] \\
\hline Bitlis tulum peyniri & 36 & 59.349 & 31.231 & $\mathbf{5 2 . 5 3 0}$ & 22.641 & 3.351 & 5.660 & 3.771 & $1.112 \% \mathrm{LA}$ & Sancak ve ark. (Bu çalışma) \\
\hline
\end{tabular}

SH: Soxhlet Henkel

Peynir örneklerinde belirlenen ortalama yağ miktarı (\%31.231 3.783$)$, bazı araştırmacıların farklı bölgelerde benzer peynirlerde tespit ettikleri değerlerden yüksek bulunmuştur (Tablo 2). İncelenen örneklerde belirlenen yağ miktarları arasında geniş bir varyasyonun (\%21.0-\%38.0) olduğu görülmüştür (Tablo 1). Bu durum kullanılan hammaddede herhangi bir standardizasyonun bulunmamasindan kaynaklanmaktadır. Bazı tüketicilerin yă̆ oranı yüksek peynirleri beğenmesi ve talep etmesi de koyun ve keçi sütü gibi yă̆ oranı yüksek sütlerin üretimde kullanılmasına neden olmaktadır. İncelenen peynirlerdeki yağ oranının yüksek bulunmasında tüketicilerin tercihlerinin önemli bir etken olduğu düşünülmektedir. Bölgede tulum peynirinin üretiminde koyun sütü kullanımı yaygındır, ancak sadece koyun sütü kullanılarak üretilen peynirler bazı tüketiciler tarafından ağır kokusundan dolayı fazla tercih edilmemektedir. İnek sütünün koyun ve keçi sütü ile karıştırılarak veya koyun/keçi sütünün birebir karışımlarının üretimde kullanılmasının, örnekler arasındaki yağ oranı farklılığının oluşmasında etkili olduğu düşünülmektedir. Türk Gıda Kodeksi Peynir Tebliği'ne göre [22] incelenen örneklerin 33’ü (\%91.67) tam yağlı tulum peyniri (kuru maddede yağ oranı $\geq \% 45)$ ve 3 'ü de (\%8.33) yağlı tulum peyniri (kuru maddede yağ oranı $<\% 45-\geq \% 25$ ) olarak sınıflandırılmıştır. Örneklerde belirlenen yağ miktarı ile tuz miktarı arasında negatif yönlü istatistiksel bir ilişki $(p<0.05)$ tespit edilmiştir. Bu durum örneklerde artan yağ miktarının tuz absorbsiyonunu olumsuz yönde etkilemesiyle ilgili olabilir. Nitekim; Gider [23] peynirin absorbe ettiği tuz miktarını süt yağının da etkilediğini, peynirlerde yağ miktarı arttıkça salamuradan tuz geçişinin yavaş olduğunu ve bu durumun süt yağının tuz absorbsiyonunu yavaşlatmasından kaynaklandığını bildirmiştir. Diğer yandan örneklerdeki yağ miktarı ile kuru maddedeki tuz miktarı arasında pozitif yönlü ve çok önemli $(p<0.01)$ bir korelasyon olması ise, üretimde kuru tuzlama ile peynirin bünyesine katılan tuzun kazein moleküllerine bağlanması ve peynir matriksinin gözeneklerine yerleşmesinden kaynaklandığı düşünülmektedir. Yağ globülleri matriksteki bu gözenekleri kapatarak peynirin tuz kaybetmesini önler ve bu durum yă̆ miktarı yüksek peynirlerde olgunlaşma süresi uzadıkça kuru maddedeki tuz oranının da artmasına neden olabilir [24].

Analize alınan peynir örneklerinde belirlenen ortalama protein miktarı (\%22.641 1.243$)$ ile bazı araştırmacıların benzer peynirlerde tespit ettikleri bulgular karşılaştırıldığında, bu araştırmada elde edilen bulguların Gönç [4], Pekel ve Korukoğlu [18] ile Morul ve İşleyici'nin [20] bulgularından düşük, Kurt ve ark. [15] ile Dığrak ve ark.'nın [16] bulgularından yüksek, Demirci [14] ile Kara ve Akkaya'nın [21] bulgularıyla benzer olduğu belirlenmiştir (Tablo 2). Bulgular arasındaki farklılıkların büyük ölçüde 
üretimde kullanılan sütlerin kalite özelliklerinden kaynaklandığı düşünülmektedir. Örneklerde tespit edilen ortalama protein miktarının, Bitlis tulum peynirinin tüketiciler için beslenmede iyi bir protein kaynağı olduğunu göstermektedir. Demirci de [25] sert peynir çeşitlerinin günlük $100 \mathrm{~g}$ tüketilmesi ile yetişkin bir insanın günlük protein ihtiyacının yaklaşık \%50-60 oranında karşılanabileceğini bildirmektedir. İncelenen örneklerdeki protein miktarı ile kuru maddede yağ $(p<0.01)$ ve kuru maddede tuz $(p<0.05)$ miktarı arasında istatistiksel yönden önemli düzeyde ilişkiler bulunmuştur. Bu ilişkiler, olgunlaştırılarak tüketilen peynirlerde olgunlaşma süresince rutubet miktarının azalmasına bağlı olarak peynirin toplam kuru madde miktarı ile kuru maddeyi oluşturan bileşenlerin göreceli olarak artmasına bağlanabilir. Ayrıca kuru maddeyi oluşturan bileşenlerden laktozun mikroorganizmalar tarafından parçalanmasıyla olgunlaşma ilerledikçe miktarı azalmakta, bu durum da kuru maddedeki yağ ve kuru maddedeki tuz miktarının daha yüksek çıkmasına neden olmaktadır. Diğer taraftan kazein ve kazein fraksiyonlarının tuzları bağlama kapasitesinin olmasının da [24], protein miktarı ile kuru maddede tuz miktarı arasında önemli düzeyde pozitif korelasyon görülmesine neden olan bir diğer faktör olduğu düşünülmektedir.

İncelenen Bitlis tulum peyniri örneklerinde belirlenen ortalama tuz miktarı (\%3.351 \pm 0.122$)$, bazı araştırmacıların $[15,16]$ benzer peynir çeşitlerinde elde ettiği değerlere yakın bulunurken, bazılarının $[18,19,20,21]$ belirlediği değerlerden düşük olduğu belirlenmiştir (Tablo 2). Türk Gida Kodeksi Peynir Tebliği'nde [22] tulum peynirlerinde kuru maddede tuz miktarının en çok \%5 olması gerektiği belirtilmiştir. İncelenen peynirlerin 14 tanesinin (\%38.89) mevzuatta belirtilen bu limit değere uygun olduğu ve 22 (\%61.11) tanesinin ise uygun olmadığ belirlenmiştir. Bitlis tulum peynirinin üretiminde \%3-4 oranında ve sabite yakın bir şekilde kaya tuzu kullanılmaktadır. İncelenen peynirlerde diğer tulum peynirlerinin çoğuna göre tuz miktarının düşük olmasının, bölge insanı tarafından sevilerek ve yaygın bir şekilde tüketilen bu peynirin çok tuzlu olarak tüketiminin tercih edilmemesine bağlı olabileceği düşünülmektedir. Ayrıca, bölgede peynir ticareti ile uğraşan tüccarlar, 25 kg'lık çuvallarda tuzsuz olarak teslim aldıkları telemenin her çuvalına yaklaşık $1 \mathrm{~kg}$ veya $100 \mathrm{~kg}$ telemeye $3 \mathrm{~kg}$ tuz düşecek şekilde tuzlama yaptıklarını ifade etmektedirler. Bu durum, peynirlerin tuzlanma oranı konusunda bölgede üreticiler tarafından çoğunlukla standart bir uygulamanın olduğunu göstermektedir.

Bitlis tulum peynirlerinde \%3.771 \pm 0.529 olarak belirlenen ortalama kül miktarının, birçok araştırmacının bildirdiği değerlerden düşük olduğu görülmektedir (Tablo 2). Peynirlerin mineral madde içeriği ve kül miktarları, üretimde kullanılan hammaddenin bileşimine ve peynir üretiminde kullanılan tekniklere bağlıdır [1, 14]. Ayrıca bu durum daha öncede belirtildiği gibi incelenen peynir örneklerinin yağ oranının yüksek olmasına ve yüksek yağ oranının kül miktarında azalmaya neden olmasına bağlanabilir.

Analizi yapılan Bitlis tulum peyniri örneklerinde ortalama titrasyon asitliği değeri laktik asit cinsinden \%1.112 \pm 0.122 olarak belirlenmiş ve bu değerin Erzincan Şavak tulum peynirlerinde belirlenen [15,16] değerlerden düşük, Divle tulum peyniri [17, 20], Kargı tulum peyniri [19], Afyon tulum peyniri [21] ile Sivas küp peynirinde [18] tespit edilen değerlere benzer veya daha yüksek olduğu görülmüştür (Tablo 2). Bölgede peynirlerin genellikle plastik bidonlarda olgunlaştırılmalarının asitliğin yüksek olmasında etkili olabileceği düşünülmektedir. Nitekim Güven [26] plastik ambalajlarda olgunlaştırılan tulum peynirlerinin asitlik düzeyinin, deri tulumlarda olgunlaştırılanlara göre daha yüksek olduğunu ve olgunlaşmanın daha kısa sürede gerçekleştiğini bildirmiştir. Bölgede plastik ambalaj materyallerindeki peynirlerin ters çevrilip toprağa gömülerek veya toprak üstünde kum ve pomza taşları ile kapatılarak olgunlaştııılması kuru madde ve asitlik değerlerinin artmasında rol oynamış olabilir. Geleneksel peynirlerde süte 1 sıl işlem uygulanmaması mikrofloranın daha güçlü kalmasına ve laktozun süratle parçalanarak titrasyon asitliği değerinin artmasına neden olmaktadır [27, 28]. Artan asitlik ise bir çok patojenin baskılanmasına ve peynirlerde istenen tat, lezzet, aroma ve tekstürü kazanmasına neden olmaktadır [29]. Sert [28] koyun sütünden üretilen peynirlerde pH değerinin, keçi sütünden üretilenlere göre daha düşük, titrasyon asitliği değerinin ise daha yüksek olduğunu bildirmektedir. Bitlis tulum peyniri üretiminde de daha çok koyun sütünün kullanılması, incelenen örneklerdeki titrasyon asitliği değerlerinin yüksek çıkmasında etkili olabilir.

\section{Sonuç ve Öneriler}

Sonuç olarak, analizi yapılan Bitlis tulum peynirlerinde tespit edilen kimyasal analiz bulguları arasında belirgin farklılıkların olması, bu peynirin üretiminde kişilere ve işletmelere göre değişen farklı 
uygulamaların olması ile birlikte belli bir standardizasyonun olmamasına, değişik olgunlaştırma şartları ve sürelerine, hammadde olarak kullanılan süt ve diğer katkı maddelerinin farklı özellikler göstermesine bağlanabilir. İncelenen Bitlis tulum peyniri örneklerinden bazılarının kimyasal kalite özellikleri açısından Türk Gıda Kodeksi Peynir Tebliği'ndeki kriterlere [22] uygun olmadığı, tespit edilen kimyasal parametreler açısından örnekler arasında önemli farklılıklar bulunduğu ve üretimde belli bir standardın bulunmadığı belirlenmiştir. Bitlis tulum peynirinin standart olarak üretilmesi durumunda, içerdiği yüksek yağ ve protein miktarları ile bölge insanının yeterli ve dengeli beslenmesinde önemli bir besin kaynağı olabileceği ortaya konmuştur. Yapılan bu ilk araştırmadan sonra Bitlis tulum peyniri üzerinde daha detaylı çalışmalar yapılması, üretiminde standart bir yöntem geliştirilmesi, kaliteli bir üretimin sağlanabilmesi için üreticilerin bilinçlendirilmesi ve piyasada satılan peynirlerin rutin bir şekilde kontrollerinin yapılması gerekmektedir. Daha modern işletmeler kurularak ve üretimde standardizasyon sağlanarak üretimin arttırılması, üretilen peynirin daha bilimsel ve bilinçli teknikler ile ulusal ve uluslararası düzeyde tanıtılarak pazarlanması önemlidir. Bitlis tulum peynirinin bölge için ekonomik katkı sağlayacak bir ürün haline gelmesi ve kalitesi ile ülkemiz geleneksel peynirleri içerisinde hak ettiği yeri alabilmesi için bölgede bulunan araştırma kuruluşları ile konuyla ilgili resmi ve sivil kurumların işbirliği yapması ve bu ürünün teşvik edilmesi gerekmektedir. Bütün bunların gerçekleştirilmesi, gelir seviyesi düşük düzeyde olan bölgenin ekonomik yönden kalkınmasına ve bölgesel turizmin gelişmesine de önemli katkılar sağlayacaktır.

\section{Teşekkür}

Bu araştırma süresince bilgi ve yardımlarını esirgemeyen Hacıgürgünoğulları Süt Ürünleri Gıda Ltd. Şti. (Yolalan/Bitlis), Öretmen Gıda Yerli Mahsulleri Süt Ürünleri (Tatvan/Bitlis) ve Yarımada İnş. Mlz. Taah. Turizm İth. İhr. San. ve Tic. Ltd. Şti. (Tatvan/Bitlis) çalışanları ile Bitlis halkına teşekkür ederiz.

\section{Kaynaklar}

[1] Fox P.F., McSweeney P.L.H. 2017. Cheese: An Overview Cheese, Edited by McSweeney PLH, Fox PF, Cotter PD, Everett DW, $4^{\text {th }}$ Ed., Academic Press, London, UK, 5-21.

[2] Kamber U. 2015. Traditional Turkey Cheeses and Their Classification, Van Veterinary Journal, 26 (3): 161-171.

[3] Yöney Z. 1970. Süt ve Mamülleri, Ankara Üniversitesi Ziraat Fakültesi Yayınları: 421, Ders Kitabı: 148, Ankara Üniversitesi Basımevi, Ankara.

[4] Gönç S. 1974. Divle Tulum Peynirinin Teknolojisi ve Bileşimi Üzerine Araştırmalar, Ege Üniversitesi Ziraat Fakültesi Dergisi, Seri A, 11 (3): 515-533.

[5] Tekinşen O.C. 2000. Süt Ürünleri Teknolojisi, 3. Baskı, Selçuk Üniversitesi Basımevi, Konya.

[6] Karaca O.B., Ocak S., Güney O., Güven M. 2007. Present Situation of Goat Production Sector and Some Typical Dairy Cheeses in Turkey, $3^{\text {rd }}$ Joint Meeting of the Network of Universities and Research Institutions of Animal Science of the South Eastern European Countries, pp 120-125, 1012 February, Thessaloniki, Greece.

[7] Kılıç S., Gönç S., Uysal H., Karagözlü C. 1998. Geleneksel Yöntemlerle ve Kültür Kullanılarak Yapılan İzmir Tulum Peynirinin Olgunlaşma Sürecinde Meydana Gelen Değişikliklerin Kiyaslanması, V. Süt ve Süt Ürünleri Sempozyumu, s: 43-64, 21-22 Mayıs, Tekirdağ.

[8] Kamber U. 2005. Geleneksel Anadolu Peynirleri, Miki Matbaacılık San. Tic. Ltd. Şti., Ankara.

[9] Hayaloglu A.A., Karagul-Yuceer Y. 2011. Utilization and Characterization of Small Ruminants Milk and Milk Products in Turkey: Current Status and New Perspectives, Small Ruminant Research, 101 (1): 73-83.

[10] Karabey B., Eroglu D., Vural C., Ozdemir G., Yerlikaya O., Kinik O. 2018. Determination of the microbial flora in traditional İzmir tulum cheeses by denaturing gradient gel electrophoresis, Journal of Food Science and Technology, 55 (3): 956-963.

[11] Kılınç Aksay E., Akar A., Cöcen İ. 2016. Pomza cevherinin hazırlanması ve zenginleştirilmesi, Afyon Kocatepe Üniversitesi Fen ve Mühendislik Bilimleri Dergisi, 16: 384-390.

[12] Kurt A., Çakmakçı S., Çağlar A. 1993. Süt ve Mamülleri Muayene ve Analiz Metodları Rehberi, Atatürk Üniversitesi Yayın No: 252/D, Ziraat Fakültesi Yayın No: 18, Genişletilmiş 5. Bask1, Erzurum. 
[13] Anonymous, 2015. IBM SPSS Statistics for Windows, Version 23.0., IBM Corp., Armonk, NY, USA.

[14] Demirci M. 1988. Ülkemizin Önemli Peynir Çeşitlerinin Mineral Madde Düzeyi ve Kalori Değerleri, Gida, 13 (1): 17-21.

[15] Kurt A., Çakmakçı S., Çağlar A., Akyüz N. 1991. Erzincan tulum (Şavak) peynirinin yapı1lış1, duyusal, fiziksel ve kimyasal özellikleri üzerinde bir araştırma, Gıda, 16 (5): 295-302.

[16] Dığrak M., Yılmaz Ö., Özçelik S. 1994. Elazığ kapalı çarşısında satışa sunulan Erzincan tulum (Şavak) peynirlerinin mikrobiyolojik ve bazı fiziksel-kimyasal özellikleri, Gıda, 19 (6): 381-387.

[17] Keleş A., Atasever M. 1996. Divle Tulum Peynirinin Kimyasal, Mikrobiyolojik ve Duyusal Kalite Nitelikleri, Süt Teknolojisi, 1 (1): 47-53.

[18] Pekel M., Korukluoğlu M. 2009. Sivas Yöresinde Üretilen Küp Peynirinin Mikrobiyolojik, Kimyasal Kalitesi ve Küf Florasının Belirlenmesi, Anadolu Tarım Bilimleri Dergisi, 24 (1): 1-7.

[19] Dinkçi N., Ünal G., Akalın A.S., Varol S., Gönç S. 2012. Kargı tulum peynirinin kimyasal ve mikrobiyolojik özellikleri, Ege Üniversitesi Ziraat Fakültesi Dergisi, 49 (3): 287-292.

[20] Morul F., İşleyici Ö. 2012. Divle Tulum Peynirinin Kimyasal ve Mikrobiyolojik Özellikleri, Yüzüncü Y1l Üniversitesi Veteriner Fakültesi Dergisi, 23 (2): 71-76.

[21] Kara R., Akkaya L. 2015. Afyon Tulum Peynirinin Mikrobiyolojik ve Fiziko-Kimyasal Özellikleri İle Laktik Asit Bakteri Dağılımlarının Belirlenmesi, Afyon Kocatepe Üniversitesi Fen ve Mühendislik Bilimleri Dergisi, 15: 1-6.

[22] Anonim, 2015. Türk Gida Kodeksi Peynir Tebliği, Tebliğ No. 2015/6, RG: 08.02.2015, 29261, Başbakanlık Basımevi, Ankara.

[23] Gider K. 2006. Beyaz Peynirlerde Tuz Geçişini Etkileyen Bazı Faktörlerin Belirlenmesi, Selçuk Üniversitesi, Fen Bilimleri Enstitüsü, Yüksek Lisans Tezi, 54s, Konya.

[24] Guinee T.P. 2004. Salting and the Role of Salt in Cheese, International Journal of Dairy Technology, 57 (2-3): 99-109.

[25] Demirci M. 1990. Peynirin Beslenmedeki Yeri ve Önemi, Gıda, 15 (5): 285-289.

[26] Güven M., Konar A. 1994. İnek Sütlerinden Üretilen ve Farklı Materyallerde Olgunlaştırılan Tulum Peynirlerinin Fiziksel, Kimyasal ve Duyusal Özellikleri, Gıda, 19 (5): 287-293.

[27] Çalım H.D. 2007. Konya ve Çevresinde Farklı Tip Ambalajlarda Tüketime Sunulan Tulum Peynirlerinin Kalite Nitelikleri, Selçuk Üniversitesi, Sağlık Bilimleri Enstitüsü, Doktora Tezi, 130s, Konya.

[28] Sert D. 2011. Geleneksel Yöntemle Üretilen Tulum Peynirlerinde Kullanılan Sütün Orijinine Bağl1 Olarak Olgunlaşma Esnasında Meydana Gelen Bazı Değişmelerin Belirlenmesi, Selçuk Üniversitesi, Fen Bilimleri Enstitüsü, Doktora Tezi, 222s, Konya.

[29] Tarakçı Z., Küçüköner E., Sancak H., Ekici K. 2005. İnek sütünden üretilerek cam kavanozlarda olgunlaştırılan tulum peynirinin bazı özellikleri, Yüzüncü Yıl Üniversitesi Veteriner Fakültesi Dergisi, 16 (1): 9-14. 